\title{
ASSOCIATION OF VIRULENCE FACTOR (PANTON-VALENTINE LEUKOCIDIN) WITH MECA GENE IN STAPHYLOCOCCUS AUREUS ISOLATES IN TERTIARY CARE HOSPITAL
}

\author{
NILIMA R PATIL, GHORPADE MV*
}

${ }^{1}$ Department of Microbiology, Research Scholar, Krishna Institute of Medical Sciences, Karad, Maharashtra, India. ${ }^{2}$ Department of Microbiology, Krishna Institute of Medical Sciences, Karad, Maharashtra, India. Email: mvghorpade611@gmail.com

Received: 11 April 2017, Revised and Accepted: 30 October 2017

\begin{abstract}
Introduction: The pathogenicity of Staphylococcus aureus depends on various bacterial surface components and extracellular proteins. S. aureus expresses a variety of virulence factors, including Panton-Valentine leukocidin (pvl). pvl is a cytotoxin produced by $S$. aureus that causes leukocyte destruction and tissue necrosis. Despite the presumed importance of $p v l$ as a virulence factor, few data are available on its prevalence among $S$. aureus isolates in our area.
\end{abstract}

Objectives: This study was aimed to determine the association between mecA gene and virulence genes such as $p v l$ gene in strains of $S$. aureus and to determine the prevalence of the $p v l$ gene in $S$. aureus isolates using the polymerase chain reaction (PCR) technique.

Methods: A total of 200 non-repeated, confirmed clinical isolates of $S$. aureus were used from various departments. Cefoxitin (30 ug) disc diffusion method was used as phenotypic method for detection of methicillin-resistant S. aureus (MRSA). We used PCR amplification to test for the $p v l$ and mecA gene in S. aureus isolates.

Results: Of 200 strains of $S$. aureus isolated in our hospital, 60 (30\%) were identified as MRSA based on cefoxitin disc diffusion method. These same 30 isolates were confirmed for mecA gene by PCR. All strains had mecA gene. All mecA positive strains of $S$. aureus were tested for pvl gene. Of 200 S. aureus, 123 (61.5\%) strains were pvl positive. Among which 33 (55\%) were pvl positive MRSA and 90 (64.28\%) pvl positive methicillin-susceptible S. aureus (MSSA) strains.

Conclusion: The prevalence of the $p v l$ among the MRSA isolates was found relatively higher in number among pus samples which indicate a possible key role of $p v l$ in pathogenesis of pyogenic infections, especially skin and soft tissue infections in community setting.

Keywords: Panton-Valentine leukocidin, Cefoxitin disc diffusion method, mecA, Staphylococcus aureus, Methicillin-resistant S. aureus, methicillinsusceptible $S$. aureus.

(C) 2018 The Authors. Published by Innovare Academic Sciences Pvt Ltd. This is an open access article under the CC BY license (http://creativecommons. org/licenses/by/4. 0/) DOI: http://dx.doi.org/10.22159/ajpcr.2018.v11i2.19080

\section{INTRODUCTION}

Staphylococcus aureus is the most virulent Staphylococcus species. $S$. aureus can cause variety of infections, ranging from minor skin infections to post-operative wound infections. One major obstacle for the treatment of $S$. aureus infections is the development of antibiotic resistance in the isolates. This resistance phenomenon originated with penicillin, the first broad-spectrum antibiotic, which was discovered in the 1940s. Its adaptive power to antibiotics has resulted in the emergence of methicillin-resistant $S$. aureus (MRSA) in the beginning of the 1960s. Methicillin resistance is mediated by an acquired penicillinbinding protein, $\mathrm{PBP} 2 \mathrm{a}$, a peptidoglycan transpeptidase encoded by the mecA gene that has low affinity for beta-lactams. Thus, when the four native peptidoglycan synthetases (penicillin-binding proteins $1,2,3$, and 4) are bound and inactivated by beta-lactams, PBP2a can still affect cell wall synthesis. mecA is harbored on the Staphylococcal chromosomal cassette mec (SCCmec), a genetic element that integrates site-specifically into the $S$. aureus chromosome [1].

MRSA strains are particularly serious and potentially lethal pathogens that possess virulence mechanisms including toxins, adhesions, enzymes, and immunomodulators [2]. Virulence genes play very important roles in bacterial pathogenesis [3] and S. aureus could not be an exception to this. It was in view of this that some of the virulence genes such as Panton-Valentine leukocidin $(p v l)$, exfoliating toxin A, and toxic shock syndrome were screened for with the hope one of the virulence genes could be incriminated in S. aureus infections.

Initially, MRSA infections were observed in hospitalized patients and those with chronic illnesses. These types of infections are caused by strain of $S$. aureus labeled as hospital-acquired MRSA (HA-MRSA). In 1990s, another type of MRSA strain was emerged that primarily causes skin and soft tissue infections in healthy people. It is called communityacquired MRSA (CA-MRSA) [4].

Molecular characterization of SCCmec types of MRSA is very essential for studying the epidemiology of MRSA. This problem is further confounded by the recent spread of CA-MRSA and the identification of vancomycin-resistant MRSA. In addition to the limited treatment options, $S$. aureus strains acquire and express numerous virulence determinants that continue to increase its ability to cause a wide spectrum of human disease $[5,6]$.

$p v l$ is a pore-forming toxin secreted by some $S$. aureus strains which destroy leukocytes by creating pores in the mitochondrial membrane and associated with skin and soft tissue infections. $p v l$ is a virulence factor associated with severe MRSA infections for which routine detection is time-consuming and dependent on the culture environment [7]. 
Moreover, the $p v l$ is encoded by a bi-cistronic operon known as lukF-PV/ lukS- $P V$ gene. Epidemiologic and clinical data $[8,9]$ provide compelling evidence that the high virulence potential of CA-MRSA is associated with the genes lukS-PV and lukF-PV encoding the subunits of the $p v l$ and has also been used as an additional marker alongside SCCmec IV and V to classify MRSA into CA-MRSA, though not all CA-MRSA carry the pvl genes.

Molecular typing techniques have been used with increasing frequency in studies of the epidemiology of MRSA and also for rapid detection of MRSA clones and virulent genes also [10-12]

Community-acquired and hospital-acquired MRSA both of these contain $m e c A$ gene. As the mec $A$ gene is essential for acquiring resistance of MRSA strains, the $p v l$ gene is an additional factor which is seen in community-acquired strains [13]. Identification of mecA positive strains can be used as a guide for separating infected patients from others in hospital environment to prevent gene transfer among clinical strains and also the distribution of virulent factors.

Having knowledge about the prevalence of MRSA and their virulence factors is useful for treatment and control of community- and hospitalacquired $S$. aureus infections.

\section{Aim and objectives}

To determine the association between $m e c A$ gene and $p v l$ gene in strains of $S$. aureus isolated from hospitalized patients for grouping the MRSA isolates into community- and hospital-acquired MRSA genetically and to determine the prevalence of the $p v l$ gene in $S$. aureus isolates using the polymerase chain reaction (PCR) technique.

\section{METHODS}

This study was the prospective type of study, carried out at Bharati Vidyapeeth Medical and Dental college, Sangli, Krishna Institute of Medical Science, Karad and Regional medical research center, ICMR, Regional center, Belgaum

\section{Inclusion criteria}

A total of 200 non-repeated clinical isolates of $S$. aureus as per statistical calculation from various clinical specimens such as blood, pus, surgical site, wounds, sputum, tracheal aspirates, and urine were included in this study. Isolates were identified as $S$. aureus based on morphology, colony characteristics, and biochemical reactions as per the standard protocol. All clinical isolates of $S$. aureus confirmed by phenotypic tests as per Clinical Laboratory Standard Institute (CLSI) guideline $[14,15]$. Antibiotic sensitivity testing of isolates of $S$. aureus to various antimicrobial discs was carried out using Kirby-Bauer disc diffusion method. All antimicrobial discs were obtained from Hi-Media Laboratories Pvt. Ltd. Mumbai, India.

\section{Detection of MRSA}

Phenotypic method: Cefoxitin (30 ug) disc diffusion method

All testing was done according to the CLSI as well as the manufacturer's recommendations. All confirmed $S$. aureus strains were tested for methicillin resistance by the Kirby-Bauer disc diffusion method using cefoxitin disc $(30 \mu \mathrm{g})$ diffusion method. Zone diameters $\leq 19 \mathrm{~mm}$ were reported as methicillin-resistant and $\geq 22 \mathrm{~mm}$ was considered as methicillin sensitive [16].

\section{Genotypic identification of MRSA (MecA-based PCR)}

PCR for the detection of mecA gene is done at molecular laboratory of ICMR Regional center, Belgaum, by following method of Unal et al. [17]. Primer sequences used for mecA detection were as follows:

- 5'- AAT CTT TGT CGG TAC ACG ATATTC TTC ACG -3'

- 5'-CGT AATGAG ATT TCA GTA GAT AAT ACA ACA -3' (Amplicon size 310bp).
Bacterial DNA was extracted from overnight cultures of $S$. aureus by CTAB- NaCl method [18].

The quality and quantity of isolated DNA was determined using Nanodrop 1000 spectrophotometer (JH Biosciences, USA. Model: ND1000) at $260 / 280 \mathrm{~nm}$ as well as visually by horizontal gel electrophoresis in 1\% agarose. Briefly, $1 \mu \mathrm{l}$ of $60 \mathrm{ng}$ of the extracted DNA was added to $24 \mu \mathrm{l}$ of PCR amplification mix consisting of $16 \mu \mathrm{l}$ of double-distilled autoclaved water, $2.5 \mu \mathrm{l}$ of $\times 10$ Taq buffer, $1 \mu \mathrm{l}$ of $2.5 \mathrm{mM}$ dNTP mix (Merck, India), $0.5 \mu \mathrm{l}$ of $3 \mathrm{U} / \mu \mathrm{l}$ Taq polymerase (Merck, India), and $0.5 \mathrm{mM}$ of each primer. The $m e c A$ gene was amplified using the primers (Sigma, India) as described by Jonas et al., 1999 [19]. Amplifications were carried out in a thermal cycler (iCycler, BioRad Inc., USA) with conditions that consisted of 30 cycles of denaturation at $94^{\circ} \mathrm{C}$ for $45 \mathrm{~s}$, annealing at $50^{\circ} \mathrm{C}$ for $45 \mathrm{~s}$, and extension at $72^{\circ} \mathrm{C}$ for $1 \mathrm{~min}$ with a final extension at $72^{\circ} \mathrm{C}$ for $2 \mathrm{~min}$. Amplicons of $310 \mathrm{bp}$ were consistent with mecA gene amplification. The PCR products were subjected to agarose gel electrophoresis using gel red dye and images were acquired using Alpha Imager gel documentation system (JH biosciences, USA. Model: D E 400).

S. aureus ATCC 25923 ( $m e c A$ negative) and ATCC 43300 (mecA positive) were used as controls for all phenotypic tests and genotypic test. The sensitivity and specificity of each test were calculated using the PCR results as a gold standard test.

\section{Detection of $p v l$ genes}

PCR was performed on all the isolates to detect $p v l$ gene. PCR for the detection of pvl gene was carried out using Cabrera et al. method [20]. Primer sequences used for $p v l$ detection were as follows:

- $\quad$ luk-PV-1, 5' - ATC ATT AGG TAA AAT GTC TGG ACA TGA-3'

- luk-PV-2, 5' - GCA TCA AGT GTA TTG GAT AGC AAA AGC-3' (Amplicon size $433 \mathrm{bp}$ )

Each primer had a concentration of $1 \mu \mathrm{M}$ while the Taq mix made up of the following: $10 \mathrm{mM}$ of $\mathrm{MgCl} 2,0.2 \mathrm{mM}$ of dNTP mix, and $1 \mathrm{U}$ of Taq polymerase (NEB, USA). For detection of $P V L$ gene, amplification was carried out with denaturation at $94^{\circ} \mathrm{C}$ for $30 \mathrm{~s}$, annealing at $55^{\circ} \mathrm{C}$ for $30 \mathrm{~s}$, and extension at $72^{\circ} \mathrm{C}$ for $1 \mathrm{~min}$ for 35 cycles of amplification. The expected product size was $433 \mathrm{bp}$.

\section{RESULTS}

A total of 200 isolates of $S$. aureus from various clinical specimens were subjected to MRSA screening as well as to check their antibiotic sensitivity pattern. Maximum (61\%) isolates were from pus sample and least from urine (5.4\%). The prevalence of MRSA was different among various clinical specimens. Frequency of isolating MRSA was maximum from wound swab and pus (56.60\%) specimens, followed by blood, fluid, and urine specimens (Graph 1).

Among all clinical samples, pus from wound infections was in highest number from which $p v l$ positive MRSA was isolated.

In this study, out of 60 MRSA, 45 strains were CA-MRSA and 15 strains were HA-MRSA. Of 140 methicillin-susceptible S. aureus (MSSA) strains, 100 strains were CA-MSSA and 40 strains were HA-MSSA (Table 1).

Of 200 strains of $S$. aureus isolated in our hospital, 60 (30\%) were identified as MRSA based on cefoxitin disc diffusion method. These same isolates were confirmed for mecA gene by PCR. All strains had mecA gene. All strains were tested for pvl gene. Of which total 123 (61.5\%) strains were $p v l$ positive. Among which 33 (55\%) strains had both $p v l$ and $m e c A$ gene and 90 (64.28\%) strains had only $p v l$ but not $m e c A$ gene (Table 2). 


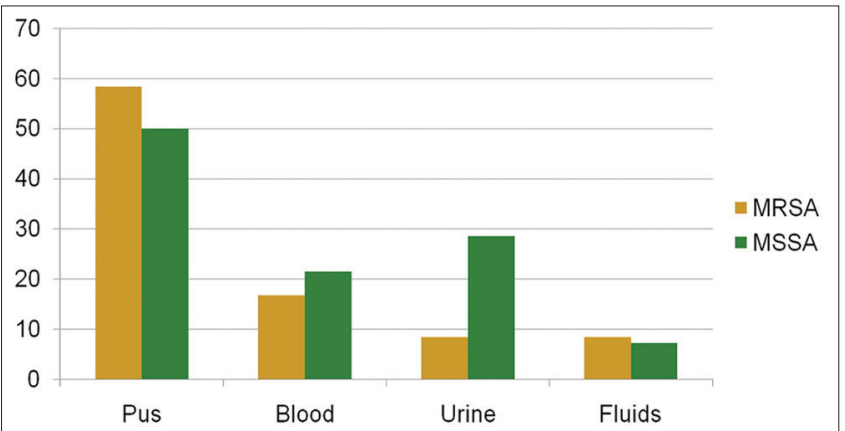

Graph 1: Sample wise prevalence of methicillin-resistant $S$. aureus and methicillin-susceptible $S$. aureus

Table 1: Prevalence of community-associated and hospital-associated strains of $S$. aureus

\begin{tabular}{llll}
\hline Type of strain & $\begin{array}{l}\text { Community- } \\
\text { associated } \\
\text { strains }\end{array}$ & $\begin{array}{l}\text { Hospital- } \\
\text { associated } \\
\text { strains }\end{array}$ & Total \\
\hline MRSA (mecA+ve) & 45 & 15 & 60 \\
MSSA (mecA -ve) & 100 & 40 & 140 \\
Total & 145 & 55 & 200 \\
\hline
\end{tabular}

MRSA: Methicillin-resistant S. aureus, MSSA: Methicillin-susceptible

S. aureus, S. aureus: Staphylococcus aureus

Table 2: The percentage of $p v l$ gene among MRSA and MSSA isolates

\begin{tabular}{lllll}
\hline Type of strains & pvl+ve & pvl -ve & Total & p value \\
\hline MRSA (mecA+ve) & $33(55)$ & $27(45)$ & 60 & $\mathrm{p}>0.5$ \\
MSSA (mecA -ve) & $90(64.28)$ & $50(35.71)$ & 140 & $\mathrm{p}<0.001$ \\
Total & $123(61.5)$ & $77(38.5)$ & 200 & $\mathrm{p}<0.005$ \\
\hline
\end{tabular}

MRSA: Methicillin-resistant S. aureus, MSSA: Methicillin-susceptible S. aureus, S. aureus: Staphylococcus aureus

\section{DISCUSSION}

According to the results of this study, $30 \%$ of isolates identified as MRSA which were positive for $m e c A$ gene. Indian network for surveillance of antimicrobial resistance (INSAR) group, a multihospital-based study in various parts of India shown that the overall MRSA prevalence in India was $42 \%$ in 2008 and $40 \%$ in 2009 [21].

Our study correlates with Indian study by Mehta et al. reported $31.8 \%$, Vidya et al. reported $29.1 \%$, and Kumari et al. from Nepal reported 26.14\% prevalence of MRSA in their study [22-24]. Our MRSA prevalence is less than study by Dr. S. Kulakarni et al. reported higher incidence of $70.3 \%$ [25].

The prevalence of MRSA was different among various clinical specimens. Frequency of isolating MRSA was maximum from wound swab and pus (56.60\%) specimens, followed by blood, fluid, and urine specimens. Our result correlates with study of Hossein et al. [26].

The occurrence of $p v l$ gene in previous studies has been reported from $2 \%$ to $35 \%[27,28]$. The $p v l$ positive strains lead to infections with different clinical appearance even in immunocompramised patients lead to necrotic pneumonia, which its mortality can be as much as 75\% [29]. Therefore, frequent monitoring of this pathogen, its antibiotic susceptibility and determining their virulence factors are of great importance in control and treatment of infections.

$p v l$ was considered as important marker for differentiation of HA-MRSA and CA-MRSA. In this study, out of 145 community-associate $S$. aureus isolates, 108 strains had pvl. However, some studies have shown positive association of $p v l$ genes among HA-MRSA isolates. $p v l$ is more commonly seen in CA-MRSA as compared to HA-MRSA.

A study conducted by Okon et al., there was no colocalization of $p v l$ and mecA genes on the genome of all the $S$. aureus strains examined, i.e., it was only possible to have $p v l$ or mecA genes but not both genes on the chromosome of the $S$. aureus isolates [30].

Reports from various countries show the increasing prevalence of $p v l$ among MRSA isolates. Kaur et al. from India, have reported overall 62.85\% of $p v l$ prevalence among MRSA and MSSA (MRSA: 85.1\% and MSSA: $48.8 \%$ ) which indicates a higher prevalence among MRSA than our findings [31]. A similar study by D'Souza et al. from Mumbai, India, reported prevalence of $64 \%$ pvl positive isolates among MRSA [32].

A number of investigations have provided evidence that the prevalence of the $p v l$ gene is high among MSSA [33].

Our findings suggested that though the prevalence of the $p v l$ toxin varied in different geographical regions, in our region, the MRSA strains may be important reservoirs of the pvl toxin, which was now being slowly acquired by the MSSA strains.

\section{CONCLUSION}

We did not find any significant association of $p v l$ gene with mecA gene. $p v l$ was more associated with community-associated strains of MRSA and MSSA. The prevalence of the $p v l$ among the MRSA isolates was found relatively higher in number among pus samples which indicate a possible key role of $p v l$ in pathogenesis of pyogenic infections, especially skin and soft tissue infections in community setting. We can be concluded that the presence of $p v l$ can be used as a reliable marker for CA-MRSA

\section{REFERENCES}

1. Ito T, Ma XX, Takeuchi F, Okuma K, Yuzawa H, Hiramatsu K, et al. Novel type V staphylococcal cassette chromosome mec driven by a novel cassette chromosome recombinase, ccrC. Antimicrob Agents Chemother 2004:48:2637-51

2. Korn GP, Martino MD, Mimica IM, Mimica LJ, Chiavone PA, Musolino LR, et al. High frequency of colonization and absence of identifiable risk factors for methicillin-resistant Staphylococcus aureus (MRSA)in intensive care units in Brazil. Braz J Infect Dis 2001;5:1-7.

3. Foster TJ. Immune evasion by staphylococci. Nat Rev Microbiol 2005;3:948-58.

4. Watkins RR, David MZ, Salata RA. Current concepts on the virulence mechanisms of meticillin-resistant Staphylococcus aureus. J Med Microbiol 2012;61:1179-93.

5. Diep BA, Chambers HF, Graber CJ, Szumowski JD, Miller LG, Han LL, et al. Emergence of multidrug-resistant, communityassociated, methicillin-resistant Staphylococcus aureus clone USA300 in men who have sex with men. Ann Intern Med 2008;148:249-57.

6. Gilbert M, MacDonald J, Gregson D, Siushansian J, Zhang K, Elsayed S, et al. Outbreak in alberta of community-acquired (USA300) methicillin-resistant Staphylococcus aureus in people with a history of drug use, homelessness or incarceration. CMAJ 2006;175:149-54.

7. Lina $\mathrm{G}$, Piémont $\mathrm{Y}$, Godail-Gamot $\mathrm{F}$, Bes $\mathrm{M}$, Peter MO, Gauduchon $\mathrm{V}$, et al. Involvement of panton-valentine leukocidinproducing Staphylococcus aureus in primary skin infections and pneumonia. Clin Infect Dis 1999;29:1128-32

8. Vandenesch F, Naimi T, Enright MC, Lina G, Nimmo GR, Heffernan H, et al. Community acquired methicillin-resistant Staphylococcus aureus carrying Panton-Valentine leukocidin genes: Worldwide emergence. Emerg Infect Dis 2003;9:978-84

9. Gillet Y, Issartel B, Vanhems P, Fournet JC, Lina G, Bes M, et al. Association between Staphylococcus aureus strains carrying gene for panton-valentine leukocidin and highly lethal necrotising pneumonia in young immunocompetent patients. Lancet 2002;359:753-9.

10. Mehndiratta PL, Bhalla P, Ahmed A, Sharma YD. Molecular typing of methicillin-resistant Staphylococcus aureus strains by PCR-RFLP of SPA gene: A reference laboratory perspective. Indian J Med Microbiol 2009;27:116-22.

11. Zhang K, McClure J, Elsayed S, Louie T, Conly J. Novel multiplex PCR 
assay for characterization and sub typing of staphylococcal cassette chromosome mec Types I to V in methicillin-resistant Staphylococcus aureus. J Clin Microbiol 2005;43:5026-33.

12. Touaitia R, Bektache S, Boutefnouchet N, Djahoudi A, Bachtarzi M. Molecular characterization of methicillin-resistant staphylococcus aureus isolated from clinical cases in East Algeria. Asian J Pharm Clin Res 2017;10:59-61.

13. Ramdani-Bouguessa N, Bes M, Meugnier H, Forey F, Reverdy ME, Lina G, et al. Detection of methicillin-resistant Staphylococcus aureus strains resistant to multiple antibiotics and carrying the panton-valentine leukocidin genes in an algiers hospital. Antimicrob Agents Chemother 2006;50:1083-5.

14. Clinical Laboratory Standards Institute (CLSI). Zone diameter interpretive standards and equivalent minimal inhibitory concentration (mic) breakpoints for Staphylococcus spp., Performance Standards for Antimicrobial Susceptibility Testing; Eighteenth Informational Supplement. CLSI Document. M100-S18. Vol. 208. Wayne, PA: Clinical Laboratory Standards Institute; 2008. p. 48.

15. Baird D. Staphylococcus: Cluster-forming gram-positive cocci. In: Collee JG, Fraser AG, Marmion BP, Simmons A, editors. Mackie $\&$ McCartney Practical Medical Microbiology. $14^{\text {th }}$ ed. New Delhi: Elsevier, A Divisionof Reed Elsevier India Pvt. Limited; 1996.

16. Patil NR, Gadagil S. Performance of chrom agar medium and conventional methods for detection of methicillin-resistant Staphylococcus aureus. Asian J Pharm Clin Res 2016;9:136-9.

17. Unal S, Werner K, DeGirolami P, Barsanti F, Eliopoulos G. Comparison of tests for detection of methicillin-resistant Staphylococcus aureus in a clinical microbiology laboratory. Antimicrob Agents Chemother 1994;38:345-7.

18. Ausubel FM, Brent R, Kingston R, Moore DE, Seidman JG, Smith JA, et al. Short Protocols in Molecular Biology. $4^{\text {th }}$ ed. New York: John Wiley and Sons Inc.; 1999

19. Jonas D, Grundmann H, Hartung D, Daschner FD, Towner KJ, Evaluation of the mecA femB duplex polymerase chain reaction for detection of methicillin-resistant Staphylococcus aureus. Eur J Clin Microbiol Infect Dis 1999; 18:643-7.

20. Cabrera EC, Ramirez-Argamosa DT, Rodriguez RD. Prevalence of community-acquired methicillin resistant $S$. aureus from inmates of the Manila city jail, characterization for SCC mec Type and occurance of PVL gene. Philipp Sci Lett 2010;3:4-12.

21. Indian Network for Surveillance of Antimicrobial Resistance (INSAR) group, India. Methicillin resistant Staphylococcus aureus (MRSA) in India: Prevalence \&amp; susceptibility pattern. Indian J Med Res 2013;137:363-9.

22. Pai V, Rao VI, Rao SP. Prevalence and antimicrobial susceptibility pattern of methicillin-resistant Staphylococcus aureus [MRSA] isolates at a tertiary care hospital in mangalore, South India. J Lab Physicians 2010;2:82-4

23. Patil NR, Ghorpade MV. Prevalence and antimicrobial resistance pattern of methicillin resistant Staphylococcus aureus (MRSA) strains in tertiary care hospital-a prospective study. World J Pharm Res 2015;4:1681-90.

24. Kumari N, Mohapatra TM, Singh YI. Prevalence of methicillin resistant Staphylococcus aureus [MRSA] in a tertiary care hospital in Eastern Nepal. J Nepal Med Assoc 2008;47:53-6.

25. Kulkarni S, Khare A, Kaur DC. Prevalence of methicillin resistant Staphylococcus aureus-A study in a tertiary care rural hospital. Indian J Basic Appl Med Res 2014;3:414-21.

26. Motamedi H, Rahmat Abadi SS, Moosavian SM, Torabi M. The association of panton-valentine leukocidin and mecA genes in methicillin-resistant Staphylococcus aureus isolates from patients referred to educational hospitals in Ahvaz, Iran. Jundishapur J Microbiol 2015;8:e22021.

27. Melles DC, Gorkink RF, Boelens HA, Snijders SV, Peeters JK, Moorhouse MJ, et al. Natural population dynamics and expansion of pathogenic clones of staphylococcus aureus. J Clin Invest 2004;114:1732-40.

28. Shashindran N, Nagasundaram N, Thappa DM, Sistla S. Can panton valentine leukocidin gene and clindamycin susceptibility serve as predictors of community origin of MRSA from skin and soft tissue infections? J Clin Diagn Res 2016;10:DC01-4.

29. McClure JA, Conly JM, Lau V, Elsayed S, Louie T, Hutchins W, et al. Novel multiplex PCR assay for detection of the staphylococcal virulence marker panton-valentine leukocidin genes and simultaneous discrimination of methicillin-susceptible from -resistant staphylococci. J Clin Microbiol 2006;44:1141-4.

30. Okon KO, Basset P, Uba A, Lin J, Oyawoye B, Shittu AO, et al. Cooccurrence of predominant panton-valentine leukocidin-positive sequence type (ST) 152 and multidrug-resistant ST 241 Staphylococcus aureus clones in Nigerian hospitals. J Clin Microbiol 2009;47:3000-3.

31. Kaur H, Purwar S, Saini A, Kaur H, Karadesai SG, Kholkute SD, et al. Status of methicillin resistant Staphylococcus aureus infections and evaluation of PVL producing straSins in Belgaum. J Krishna Inst Med Sci Univ 2012;1:43-51

32. D'Souza N, Rodrigues C, Mehta A. Molecular characterization of methicillin-resistant Staphylococcus aureus with emergence of epidemic clones of sequence Type (ST) 22 and ST 772 in Mumbai, India. J Clin Microbiol 2010;48:1806-11.

33. Ghebremedhin B, Olugbosi MO, Raji AM, Layer F, Bakare RA, König B, et al. Emergence of a community-associated methicillinresistant Staphylococcus aureus strain with a unique resistance profile in Southwest Nigeria. J Clin Microbiol 2009;47:2975-80. 